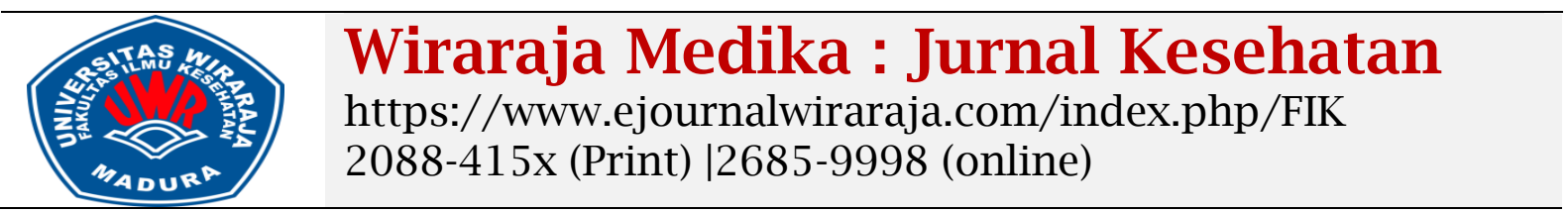

\title{
Kepatuhan Diet dengan Kualitas Hidup Pasien Hemodialisa di RSUP Dr. Soeradji Tirtonegoro: Korelasi Studi
}

\author{
Heru Ginanjar Triyono ${ }^{1}$, Dian Novita $\mathrm{K}^{2}$, Sugiarto ${ }^{3}$, Tengku Isni Yuli ${ }^{4}$, Winda Rofiyati ${ }^{5}$ \\ 1,3,4,5,Prodi Ners Universitas Alma Ata Yogykarta \\ ${ }^{2}$ Akper Karya Bakti Husada Yogyakarta
}

1'heru@almaata.ac.id*; ${ }^{2}$ diannovita2486@yahoo.com, ${ }^{3}$ sugiarto@almaata.ac.id,

${ }^{4}$ tengkuisni15@almaata.ac.id, ${ }^{5}$ windarofiyati@almaata.ac.id

*Corresponding author

\begin{tabular}{ll}
\hline Informasi artikel & ABSTRAK \\
\hline Sejarah artikel: & Ginjal merupakan salah satu organ tubuh yang memiliki fungsi penting \\
Received: 27-07-2020 & dalam tubuh. Fungsi-fungsi ini termasuk mengatur konsentrasi garam \\
Revised: 23-11-2020 & dalam darah, dan mengatur keseimbangan asam basa dan ekskresi garam \\
Accepted: 29-11- & berlebih. Tujuan penelitian mengetahui diet dengan kualitas hidup pasien \\
2020 & Hemodialisa di Rs DR soeradji tirtonegoro Desain penelitian ini adalah \\
Kata kunci: & analitik dengan simple Random Sampling. Penelitian yang menggunakan \\
Kepatuhan & tipe deskriptif kuantitatif menggunakan cross sectional. Desain cross \\
Diet Gagal Ginjal & sectional merupakan penelitian dimana peneliti hanya melakukan \\
Kualitas Hidup & pengamatan dan mengukur variabel pada satu waktu. Pengambilan sampel \\
Hemodialisa & dalam penelitian ini. Pengambilan sampel dalam penelitian ini adalah 30 \\
& responden yang menjalani hemodialisis. Jumlah tersebut diperoleh \\
& berdasarkan data jumlah pasien. Hasil analisis hubungan kepatuhan diet \\
& dengan kualitas hidup pasien hemodialisis di Rumah Sakit menggunakan \\
& uji chi square. Hasil uji korelasi chi suare diperoleh nilai sig (2-tailed) \\
& dengan hasil nilai 0,003 p <0,05 hingga 0,003 <0,05 menunjukkan \\
& hubungan antara kepatuhan diet dengan kualitas hidup. Data yang \\
& dihasilkan dari analisis bivariat responden yang memenuhi kualitas hidup \\
& yang baik adalah 14 responden (66,7\%), sedangkan responden yang tidak \\
& patuh dan dengan kualitas hidup yang lebih rendah adalah 4 responden \\
& (44,4\%). kualitas hidup kurang disebabkan oleh tingkat pendidikan yang \\
& kurang sehingga pasien kurang memahami prinsip diet gagal ginjal yaitu \\
& rendah protein, rendah kalium dan rendah natrium yang merupakan salah \\
& satu penatalaksanaan untuk mempertahankan fungsi ginjal secara terus \\
& menerus dan mengurangi komplikasi
\end{tabular}

Key word:

Diet

Kidney Failure

Quality Of Life

Hemodialysis

\section{ABSTRACT}

Kidney is one the organs that has an important function in the body. These functions include regulating the concentration of salt in the blood, and regulating the balance of acid base and the excretion of excess salt.Design Of this study was analytic with total Random Sampling. Research that uses descriptive quantitative type using cross sectional. This researcher only observed and measured variables without giving treatment. Cross sectional design or cross-sectional study, researchers only make observations and measure variables at one time. The Sampling in this study. The sampling in this study were 30 respondents who underwent hemodialysis. The amount was obtained based on data on the number of patients. The results of the analysis of the relationship of diet adherence with the quality of life of hemodialysis patients at Hospital using the chi square test. From table 4.4 the chi suare correlation test results obtained sig (2-tailed) values with the results of $0.003 p$ value $<0.05$ to $0.003<0.05$ showed a relationship between diet compliance with quality of life. Data generated from the bivariate analysis of respondents who comply with good quality of life were 14 respondents (66.7\%), while respondents who were not compliant and with less quality of life were 4 respondents (44.4\%). 


\section{PENDAHULUAN}

Data Indonesian Renal Registry, 2012 pasien yang menderita gagal ginjal berdasarkan diagnosa etiologi yaitu, DKI Jakarta sebanyak 1.033 orang, Jabar sebanyak 3.918 orang, Jateng sebanyak 3069 orang, Bali sebanyak 1.732 orang, Sumut sebanyak 394orang, Sumbar sebanyak 153 orang, Sulawesi 206 orang, dan Kalimantan sebanyak 665. Total keseluruhan diIndonesia 15.993. Jumlah tindakan hemodialisis (HD) di Indonesia tahun2012 yaitu HD rutin 717.497 kali, HD akut 33.028 kali, HD ekstra 2.419 kali, CRRT 384 kali, Hibrid Dialisis 1.285 kali (IRR, 2018).

Yayasan Ginjal Indonesia terdapat 6,7 persen dari penduduk Indonesia mempunyai gangguan fungsi ginjal dengan tingkatan sedang sampai berat, dengan kecenderungan yang meningkat sesuai dengan kemajuan sebuah negara yang mengubah pola konsumsi masyarakatnya. Tanjung (2010) di Indonesia sekarang ini terdapat 70 ribu penderita gagal ginjal yang perlu mendapatkan perawatan berupa dialisis rutin maupun cangkok ginja(Widiany, 2017).

Penatalaksanaan GGK dapat dilakukan dengan berbagai cara diantaranya pengaturan diet, masukan kalori suplemen dan vitamin, pembatasan asupan cairan, obat- obatan, terapi penggantian ginjal seperti transplantasi ginjal dan hemodialisis (HD). Gaya hidup seperti diet merupakan penatalaksanaan yang harus dipatuhi oleh pasien GGK(Of, Cident, \& Modalities, 2018). Pasien yang tidak mematuhi hal ini, maka akan dapat mengakibatkan kenaikan berat badan yang cepat melebihi 5\%, edema, ronkhi basah dalam paru paru, kelopak mata yang bengkak dan sesak nafas(Lansia, 2013)(Anwar, 2004). Gagal ginjal kronik sangat beragam, tergantung dari penyebab penyakitnya. Glumerulosklerosis dan inflamasi interstisial dan fibrosis adalah ciri khas dari gagal ginjal dan menyebabkan penurunan fungsi ginjal. Aliran kapiler glomerulus dan meningkatnya tekanan nefron sehingga membutuhkan lebih banyak partikel zat terlarut yang disaring untuk mengkompensasi massa ginjal yang hilang. Akibat dari kerusakan glomerulus proteinuria menjadi penyebab cederanya tubulus(Medicine, 2011).

Kualitas hidup adalah kondisi sesesorang yang puas akan kehidupannya serta menganggap kebutuhan tercukupi walaupun masih mempunyai kekurangan. Kualitas hidup seseorang erat kaintannya dengan kondisi fisik dan mental. Kualitas hidup merupakan cerminan peran dan merasakan kepuasan dalam melakukan sesuatu.

Kualitas Hidup pada pasien Hemodialisa umumnya akan terganggu aktivitasnya, baik dalam bidang sosial, kesulitan tidur karena rasa sakit yang ditimbulkannya, hal ini menggambarkan kualitas hidup pasien Hemodialisa, berbagai faktor yang mempengaruhi kualitas hidup antara lain sosial dan demografi yaitu jenis kelamin, umur, suku, etnik, pendidikan. Kualitas hidup erat kaitanya dengan lifestyle dan Impact yang ditimbulkan. Lifestyle meliputi kepatuhan diet, latihan dan aktifitas.

Kepatuhan diet pasien Hemodialisa berpengaruh terhadap keseimbangan kreatinin dan urem dalam darah. Seseorang penderita hemodialisa yang patuh dengan diit akan mengkonsumsi makanan yang sesuai dengan anjuran dokter, hal ini oleh karena pasien sudah merasakan kaeadaan tubuhnya yang normal, walaupun harus ketat adalam asupan natrium dan bahan lainnya. (Baradero, M. Dayfrit, Mary Dilfrid. Siswadi, 2009; Sudoyo, 2009)

Pada stadium awal penyakit ginjal kronik terjadi penurunan daya cadang ginjal (renal reseve), namun GRF masih normal atau dapat meningkat namun secara perlahan terjadi penurun fungsi nefron ditandai dengan meningkatnya kadar kreatinin srum dan urea. Pada GFR dibawah 15\% keadaaan dimana pasien mengidap end strage renal disease akan terjadi komplikasi yang menyebabkan pasien dilanjutkan untuk menjalai renal replancement therapy antara lain dialisis atau transplantasi ginjal(Triaksono, 2016). Tujuan Penelitian ini adalah mengetahui kepatuhan diet dengan kualitas hidup pasien Hemodialisa di RSUP Dr Soeradji Tirtonegoro.

\section{METODE PENELITIAN}

Penelitian ini merupakan penelitian yang memakai jenis deskriptif yang bersifat kuantitatif dengan menggunakan cross sectional. Peneliti ini hanya mengamati dan mengukur variabel tanpa memberikan perlakuan. Desain cross sectional atau studi potong lintang, peneliti hanya melakukan observasi serta mengukur variabel pada satu waktu itu saja. Sehingga satu subyek hanya dikenai satu kali pengukuran tanpa 
harus dilakukan follow up ataupun mengulangi pengukuran. Populasi yang ada pada penelitian ini adalah seluruh pasien yang menjalankan cuci darah diruang hemodialisa 2 Dr. Soeradji Tirtonegoro Klaten). Populasi dalam penelitian ini adalah sebanyak 30 responden yang menjalani hemodialisa. Jumlah tersebut diperoleh berdasarkan data jumlah pasien yang ada di RSUP Dr. Soeradji Tirtonegoro. Teknik yang digunakan pada penelitian ini adalah simple random sampling, dimana peneliti dalam memilih subyek penelitian dengan memberikan kesempatan yang sama kepada semua anggota populasi untuk ditetapkan sebagai anggota sampel. Sampel yang dipilih harus memenuhi dalam kriteria inklusi dan eksklusi.

\section{HASIL PENELITIAN}

Tabel $\quad 1.1 \quad$ Distribusi Frekuensi berdasarkan karakteristik responden

\begin{tabular}{ccc}
\hline Karakteristik & Frekuensi & Prosentase \\
\hline $\begin{array}{c}\text { Jenis kelamin } \\
\text { Perempuan }\end{array}$ & 30 & 100 \\
Usia (tahun) & & \\
$20-30$ & 3 & 10 \\
$31-40$ & 4 & 13,3 \\
$41-50$ & 10 & 33,3 \\
$51-60$ & 9 & 30 \\
$61-70$ & 4 & 13,3 \\
\hline
\end{tabular}

Tingkat Pendidikan

$\begin{array}{ccc}\text { Tidak Sekolah } & 6 & 20 \\ \text { SD } & 4 & 13,3 \\ \text { SMP } & 4 & 13,3 \\ \text { SMA } & 13 & 43,3 \\ \text { PT } & 3 & 10\end{array}$

\begin{tabular}{ccc}
\hline Pekerjaan & & \\
PNS & 1 & 3,3 \\
Swasta & 5 & 16,7 \\
Petani & 2 & 6,7 \\
Buruh & 3 & 10 \\
Tidak Bekerja & 19 & 63,3 \\
\hline Lama Menderita & & \\
1-5 tahun & 18 & 60 \\
6-10 tahun & 8 & 26,7 \\
$>11$ tahun & 4 & 13,3 \\
\hline
\end{tabular}

\section{Sumber: Data Primer Terolah}

Hasil penelitian berdasarkan kategori usia menunjukan bahwa responden berusia 41-50 tahun yaitu sebanyak 10 orang $(33,3 \%)$ sedangkan responden dengan usia 20-30 tahun berjumlah 3 orang (10\%). Berdasarkan tingkat pendidikan sebagian besar adalah SMA sebanyak 13 responden $(43,3 \%)$ sedangkan yang berpendidikan tinggi(Sarjana dan diploma dengan jumlah 3 orang (10\%). Hasil penelitian karakteristik pekerjaan sebagian besar adalah tidak bekerja/IRT sebanyak 19 orang $(63,3 \%)$ dan yang paling sedikit adalah responden dengan pekerjaan 1 orang (3,3\%). Berdasarkan kategori lama menderita menunjukan lama menderita diabetes melitus responden terbanyak adalah 1-5 tahun yaitu sebanyak 18 orang (60\%) dan yang paling sedikit adalah lebih dari 11 tahun sebanyak 4 orang $(13,3 \%)$.

Tabel 1.2 Distribusi frekuensi berdasarkan kepatuhan diet

\begin{tabular}{ccc}
\hline \multirow{2}{*}{$\begin{array}{c}\text { Menejemen } \\
\text { Stress }\end{array}$} & \multicolumn{2}{c}{ Kepatuhan Diet } \\
\cline { 2 - 3 } & $\begin{array}{c}\text { Frekuensi } \\
\text { (F) }\end{array}$ & Prosentase (\%) \\
\hline Patuh & 21 & 70 \\
Tidak Patuh & 9 & 30 \\
Jumlah & $\mathbf{3 0}$ & $\mathbf{1 0 0}$ \\
\hline
\end{tabular}

Sumber: Data Primer Terolah

Hasil Penelitian berdasarkan Kualitas hidup pasien hemodialisa menunjukan responden terbanyak dengan kualitas hidup baik sebanyak 16 orang $(53,3 \%)$ dan kualitas hidup kurang sebanyak 4 orang $(13,3 \%)$

Tabel 1.3 Hubungan Kepatuhan diet dengan kualitas hidup pasien Hemodialisa

\begin{tabular}{|c|c|c|c|c|c|c|c|}
\hline \multirow{3}{*}{ Kepatuhan } & \multicolumn{6}{|c|}{ Kualitas hidup } & \multirow{3}{*}{$\mathbf{P}$} \\
\hline & \multicolumn{2}{|c|}{ Kurang } & \multicolumn{2}{|c|}{ Cukup } & \multicolumn{2}{|c|}{ Baik } & \\
\hline & $\mathbf{F}$ & $\%$ & $\mathbf{F}$ & $\%$ & f & $\%$ & \\
\hline Patuh & 0 & 0 & 7 & 33,3 & 14 & 67 & \\
\hline $\begin{array}{l}\text { Tidak } \\
\text { Patuh }\end{array}$ & 4 & 44 & 3 & 33,3 & 2 & 22 & 0,003 \\
\hline Jumlah & 0 & 44 & 10 & 66,6 & 16 & 89 & \\
\hline
\end{tabular}

Sumber: Data Primer Terolah

Tabel hubungan kepatuhan diet dengan kualitas hidup pasien dengan uji chi square diperoleh nilai sig (2-tailed) dengan hasil $0,003 \mathrm{p}$ value $<0,05$ jadi $0,003<0,05$ menunjukan adanya hubungan antara kepatuhan diet dengan kualitas hidup. 


\section{PEMBAHASAN}

\section{Kepatuhan diet pada pasien yang} menjalani Hemodialisis

Hasil penelitian menunjukan distribusi responden terbanyak dengan kepatuhan diet yang patuh sebanyak 21 orang (70\%) dan yang tidak patuh sebanyak 9 orang (30\%). Hal ini sejalan dengan penelitian Rahma Afissa yang menyebutkan sebanyak 68,2 \% pasien patuh menjalani diet karena menyadari bahwa malaksanakan diet pasien gagal ginjal kronik yang menjalani hemodialisa harus benar-benar dipatuhi dan dilaksanakan agar mengurangi resiko komplikasi penyakit.terhindar dari gejalagejala yang dapat mengganggu seperti sesak nafas, pembengkakan dan mual dan muntah(Rahma A, 2017). Hal ini bertolak belakang dengan penelitian Mailani Fitri yang menyatakan bahwa sebagian besar pasien tidak patuh dalam melaksanakan diet hemodialisa yaitu sebanyak $62 \%$ karena ratarata pasien merasa makanannya terasa hambar apabila makanannya tidak diberi garam atau vitsin. Hal tersebut merupakan pemicu rasa haus pada pasien sehingga membuat pasien mengkonsumsi cairan secara berlebihan(Sari A, 2017).

\section{Kualitas hidup pasien yang menjalani Hemodialisis}

Hasil penelitian menunjukan distribusi responden terbanyak dengan kualitas hidup baik sebanyak 16 orang $(53,3 \%)$ dan kualitas hidup kurang sebanyak 4 orang (13,3\%). Penelitian yang dilakukan Gerasimoula, 2015 menyebutkan sebagian besar memiliki kualitas hidup pasien hemodialisa dalam kategori baik yaitu sebanyak 57\% karena setelah melakukan hemodialysis pasien dapat melakukan aktivitasnya kembali secara produktif dan dapat meningkatkan kualitas hidupnya(Gerasimoula et al., 2015). Hal ini berbeda dengan penelitian lain yang menunjukan bahwa $61,0 \%$ pasien yang menjalani hemodialysis merasa kualitas hidupnya pada tingkat rendah dengan kondisi fisik merasa kelelahan, kesakitan dan sering gelisah, pada kondisi psikologis pasien tidak memiliki motivasi untuk sembuh. Penelitian ini sebagian besar kualitas hidup pasien hemodialisa dalam kategori baik. Salah satu faktor menyebabkan kualitas hidup baik adalah karena perilaku kesehatan dari penderita gagal ginjal kronik cukup baik. Data primer yang dikumpulkan menunjukan sebagian besar pasien hemodialisa rutin melaksanakan diet, rutin minum obat dan rutin melakukan hemodialisa sesuai jadwal(Thenmozhi, $\quad$ 2018).Hubungan kepatuhan diet dengan kualitas hidup pasien hemodialisa di RSUP Dr Soeradji Tirtonegoro Klaten dengan menggunakan uji chi square. Dari tabel 4.4 hasil uji korelasi chi suare diperoleh nilai sig (2-tailed) dengan hasil $0,003 \mathrm{p}$ value $<0,05$ jadi $0,003<0,05$ menunjukan adanya hubungan antara kepatuhan diet dengan kualitas hidup. Data yang dihasilkan dari analisis bivariat responden yang patuh dengankualitas hidup baik terdapat 14 responden (66,7\%), sedangkan responden yang tidak patuh dan dengan kualitas hidup kurang sebanyak 4 responden $(44,4 \%)$.

\section{Usia Pasien Yang Menjalani Hemodialisa}

Hasil analisis berdasarkan tabel 4.1 menunjukan bahwa sebagian responden yang menjalani hemodialisa sebagian besar berusia 41-50 tahun sebanyak 10 responden (33.3\%). Hal ini disebabkan karena semakin bertambah usia, semakin berkurang fungsi ginjal dan berhubungan dengan penurunan kecepatan ekskresi glomerulus dan memburuknya fungsi dari tubulus. Berdasarkan teori Price \& Wilson pada penyait ginjal kronik nilai GFR turun dibawah nilai normal sebesar $125 \mathrm{ml} /$ menit. GFR akan menurun sesuai bertambahnya usia, usia 30 tahun nilai GFR menurun dengan kecepatan sekitar 1 $\mathrm{ml} /$ menit/tahun.

Penelitian ini sesuai dengan penelitian sebelumnya yang membahas tentang hubungan antara usia dengan kejadiannya Gagal ginjal yang sedang dilakukan hemodialisa yang menunjukan bahwa rata-rata responden yang menjalani hemodialisa didominasi usia > 40 tahun yaitu sebanyak 57 responden (72,2\%) (34). Hasil penelitian ini juga sejalan dengan penelitian sebelumnya terkait faktor-faktor determinan pada kualitas hidup pasien gagal ginjal kronik yang menunjukan hasil bahwa dari 93 responden didapatkan sebagian besar responden berumur 40 tahun sebanyak 77 responden (83\%)(Harford, Clark, Norris, \& Yan, 2016).

\section{Jenis kelamin Pasien Yang menjalani Hemodialisa}

Analisa penelitian ini berdasarkan distribusi jenis kelamin dapat disimpulkan 
bahwa semua responden berjenis kelamin perempuan sebanyak 30 responden (100\%). Berdasarkan beberapa studi penyakit ginjal kronik lebih banyak terjadi pada perempuan dibandingkan dengan laki-laki dengan rerata prevalensi sebesar 14\% pada perempuan dan $12 \%$ pada laki-laki. Penelitian ini sejalan dengan penelitian sebelumnya yang menunjukan bahwa perempuan lebih banyak yang menjalani terapi hemodialisa yaitu sebanyak 32 responden (51,6\%)(Vongsanim \& Davenport, 2019).

\section{Pendidikan Responden}

Hasil analisis berdasarkan distribusi pendidikan pada responden didapatkan persentase paling banyak yaitu pendidikan SMA sebanyak 13 responden $(43,3 \%)$.Menurut penelitian sebelumnya mengatakan bahwa pada penderita yang memiliki pendidikan tinggi akan mempunyai pengetahuan yang lebih luas sehingga memungkinkan pasien dapat mengontrol diri dalam mengatasi masalah, mempunyai percaya diri tinggi, berpengalaman dan mempunyai perkiraan yang tepat, mudah memahami tentang apa yang dianjurkan petugas kesehatan serta mudah dalam membuat keputusan. Peneliti mengasumsikan tingkat pendidikan mempengaruhi perilaku seseorang dalam mencari perawatan dan pengobatan penyakit yang dideritanya(Manual, 2019). Penelitian ini sejalan dengan penelitian sebelumnya yang juga menunjukan bahwa responden terbanyak yaitu pendidikan terakhir SMA sebanyak 22 responden $(36,7 \%)(38)$.

\section{Pekerjaan Pasien yang menjalani Hemodialisa}

Hasil analisis berdasarkan distribusi pekerjaan menunjukan bahwa sebagian besar responden tidak bekerja yaitu sebanyak 19 responden (63.3\%). Hal ini terkait karena setelah mendapat terapi hemodialisa pasien cenderung mengalami penurunan fisik. Hal ini sejalan dengan penelitian sebelumnya yang menunjukan bahwa 49 responden (62\%) tidak memiliki pekerjaan $^{14}$.

\section{Lama menderita Gagal Ginjal Kronik}

Hasil penelitian terkait lama menjalani hemodialisa dengan kualitas hidup juga menunjukan 18 responden $(58,1 \%)$ tidak bekerja ${ }^{15}$. Hasil analisis bedasarkan distribusi lama menderita hemodialisa menunjukan bahwa yang paling banyak pada kisaran angka 1-5 tahun sebanyak 10 responden (60\%). Hal ini sejalan dengan penelitian sebelumnya terkait lama hemodialisa dengan kualitas hidup pasien penyakit ginjal kronik yang menunjukan sebagian besar tergolong cukup sebanyak 16 responden $(36,4 \%)$ pada lama terapi hemodialisa $<5$ tahun 8 .

Responden yang mempuyai tingkat kepatuhan dan memiliki kualitas hidup baik dikarenakan dengan patuh dalam menjalani diet yang dianjurkan akan mengurangi beban kerja ginjal. Salah satu kepatuhan yang dilakukan responden adalah dengan membatasi asupan cairan sesuai dengan jumlah urine yang dikeluarkan, membatasi asupan kalium dengan mengurangi mengkonsumsi manga, daun singkong, daun papaya, bayam, kacang hijau dan durian, membatasi asupan natrium dengan tidak memakan makanan kalengan, membatasi asupan protein seperti mengkonsumsi 1 butir telur, 1 potong ayam, 1 potong daging dan 4 potong tempe dalam sehari, membatasi asupan sumber energy dengan makan nasi 3 piring sedang, tidak mengkonsumsi roti dan kentang dan mengurangi gula dan gagal nafas sehingga kualitas hidup pasien dapat meningkat(Vongsanim \& Davenport, 2019).

Responden yang tidak patuh dan memiliki kualitas hidup kurang disebabkan oleh tingkat pendidikan yang kurang sehingga pasien kurang memahami prinsip diet gagal ginjal yaitu rendah protein, rendah kalium dan rendah natrium yang merupakan salah satu penatalaksanaan untuk mempertahankan fungsi ginjal secara terus menerus dan mengurangi komplikasi. Hal ini dapat dilihat dari data primer yaitu sebagian besar responden tidak sekolah dengan presentase $40 \%$.Tingkat pendidikan mempengaruhi seseorang untuk mempertahankan hidup yang sehat yaitu dengan patuh menjalankan diet pada pasien gagal ginjal yang menjalani hemodialisa. Diet dan gaya hidup sehat secara umum diketahui sebagai syarat kesehatan yang didefinisikan sebagai usaha memajukan kualitas hidup atau kesejahteraan dan pencegahan terhadap penyakit terkait gizi(Moottari ME et al, 2012)

\section{Kesimpulan}

Karakteristik data Demografi Jenis Kelamin 30 orang (100\%) berjenis kelamin perempuan. Usia respon mayoritas 41-50 
tahun 10 responden(33,3\%). Pendidikan terakhir mayoritas SMA 13 orang(43,3\%). Pekerjaan Tidak Bekerja/ ibu Ruma tangga 19orang(63,3\%), lama menderita mayoritas 15 tahun 18 responden(60\%). Kepatuhan diet Cukup Patuh 7 responden(33,3\%). Sangat patuh 14 orang(66,7\%), sedangkan 4 orang $(44,4 \%)$ tidak patuh terhadap diet yang diberikan.

Kualitas Hidup baik sebanyak 16 orang $(53,3 \%)$ dan kualitas hidup kurang sebanyak 4 orang (13,3\%). Banyak faktor yang menyebabkan kualitas hidup baik antara lain adalah karena perilaku kesehatan dari penderita gagal ginjal kronik cukup baik. Kondisi fisik dan mental sesorang akan akan berdampak secara langsung dengan tingkat keseimbangan ureum dan kreatinin dalam darah

\section{Daftar Pustaka}

Anwar, T. B. (2004). Faktor Risiko Penyakit Jantung Koroner. Universitas Sumatera Utara, (Medan), 1-15.

Baradero, M. Dayfrit, Mary Dilfrid. Siswadi, Y. (2009). Klien Gangguan Ginjal Seri Asuhan Keperawatan. jakarta: EGC.

Dharma, K. kusuma. (2011). Metodologi Penelitian Keperawatan. jakarta: Trnas Info Media.

Gerasimoula, K., Lefkothea, L., Maria, L., Victoria, A., Paraskevi, T., \& Maria, P. (2015). QUALITY OF LIFE IN HEMODIALYSIS PATIENTS, 15(August), 305-309.

https://doi.org/10.5455/msm.2015.27 .305-309

Harford, R., Clark, M. J., Norris, K. C., \& Yan, G. (2016). Relationship between Age and Pre -End Stage Renal Disease Care in Elderly Patients Treated With Hemodialysis, 43(2), 101-108.

IRR. (2018). 11 th Report Of Indonesian Renal Registry 201811 th Report Of Indonesian Renal Registry 2018, 1-46.

Kim, K., Kang, G. W., \& Woo, J. (2018). The Quality of Life of Hemodialysis Patients Is Affected Not Only by Medical but also Psychosocial Factors : a Canonical Correlation Study, 33(14), $1-11$.

Manual, P. E. (2019). Hemodialysis patient education Manual. SANFORD Health.

Medicine, D. of nephology \&Hypertension G. I. (2011). Chronic Kidney Disease (CKD).

Moottari ME et al. (2012). The effect empowerment on the self -efficacy quality of livr and clinical and laboratoy indicator of patient treated with hemodialysis.

Of, H., Cident, I. N., \& Modalities, R. (2018). Chapter 1: Incidence, Prevalence, Patient Characteristics , and Treatment Modalities, 2.

Rahma A, P. (2017). Hubungan kepatuhan diet dan kualitas hidup pasien gagal ginjal kronik yang menjalani hemodialisa di RSUD Sidoarjo. Skripsi.

Sari A. (2017). Kualitas Hidup pasien gagal ginjal kronik yang menjalani HD dan mengalami depresi. Skripsi.

Sudoyo, A. W. (2009). Buku ajar ilmu penyakit dalam (4th ed.). jakarta: Pusat Penerbitan Departemen Ilmu Penyakit Dalam FKUI.

Thenmozhi, P. (2018). Quality of life of patients undergoing hemodialysis QUALITY OF LIFE OF PATIENTS UNDERGOING HEMODIALYSIS, (April). https://doi.org/10.22159/ajpcr.2018.v $11 \mathrm{i} 4.24007$

Triaksono, N. (2016). Chronic Kidney Desease And Failure, (July). https://doi.org/10.13140/RG.2.1.4622 .2326

Vongsanim, S., \& Davenport, A. (2019). The effect of gender on survival for hemodialysis patients: Why don' $t$ women live longer than men?, 1-6. https://doi.org/10.1111/sdi.12817

Widiany, F. L. (2017). Faktor-faktor yang mempengaruhi kepatuhan diet pasien hemodialisis, 14(2), 72-79.(Kim, Kang, \& Woo, 2018) 